\title{
HUBUNGAN TINGKAT PENDIDIKAN IBU HAMIL TERHADAP FREKUENSI PEMERIKSAAN KEHAMILAN DI BPM G. N. MAYA D. TAMBAK SAWAH
}

\author{
Setiana Andarwulan \\ Program Studi D III Kebidanan, Fakultas IImu Kesehatan, Universitas PGRI Adi Buana Surabaya \\ E-mail: setianaandarwulan@unipasby.ac.id
}

\begin{abstract}
ABSTRAK
Pelayanan antenatal adalah pelayanan kesehatan yang dilaksanakan oleh tenaga kesehatan kepada ibu selama masa kehamilannya sesuai standar pelayanan antenatal yang ditetapkan. Pemanfaatan pelayanan antenatal care oleh sejumlah ibu hamil di Indonesia belum sepenuhnya sesuai dengan pedoman yang ditetapkan. Kurangnya pemanfaatan antenatal care oleh ibu hamil ini berhubungan dengan banyak faktor. Salah satu faktor diantaranya adalah pendidikan ibu hamil. Tujuan penelitian ini adalah untuk mengetahui hubungan tingkat pendidikan ibu hamil dengan frekuensi pemeriksaan kehamilan di BPM G. N. Maya D Tambak Sawah. Pelaksanaan penelitian dilakukan pada bulan Mei - Juli 2019. Penelitian ini dilaksanakan dengan metode cross sectional, yang mempunyai variabel penelitian yaitu tingkat pendidikan dan frekuensi pemeriksaan kehamilan. Jumlah populasi sebanyak 36 ibu hamil sedangkan sampel sebanyak 33 ibu hamil. Pengumpulan data dilakukan dengan pengisian kuisioner yang dibuat oleh peneliti dan diisi oleh responden. Selanjutnya data yang terkumpul diolah dengan menggunakan bantuan computer program SPSS versi 20 untuk dianalisa dengan uji chisquare dengan tingkat kemaknaan (a) 0,05 . Hasil penelitian menunjukkan tingkat pendidikan rendah sebanyak $54,5 \%$ frekuensi ketidakteraturan periksa hamil sebanyak $54,5 \%$, hubungan antara tingkat pendidikan terhadap frekuensi pemeriksaaan kehamilan adalah chi square $0,143>0,05$. Hasil dalam penelitian ini ada hubungan antara tingkat pendidikan ibu hamil dengan frekuensi pemeriksaan kehamilan.
\end{abstract}

Kata Kunci: Pendidikan, Frekuensi, Kehamilan

\begin{abstract}
Antenatal care is a health service carried out by a health worker to a mother during her pregnancy in accordance with established antenatal care standards. The use of antenatal care services by a number of pregnant women in Indonesia has not been fully in accordance with established guidelines. The lack of use of antenatal care by pregnant women is related to many factors. One of the factors is the education of pregnant women. The purpose of this study was to determine the relationship of the education level of pregnant women with the frequency of antenatal care at BPM G. N. Maya D Tambak Sawah. The research was carried out in May - July 2019. The research was carried out by cross sectional method, which has research variables, namely the level of education and the frequency of antenatal care. Total population of 36 pregnant women while the sample of 33 pregnant women. Data collection is done by filling out questionnaires made by researchers and filled out by respondents. Furthermore, the data collected was processed using SPSS version 20 computer program help to be analyzed by Chi-square test with a significance level ( $\alpha$ ) of 0.05 . The results showed a low level of education as much as $54.5 \%$ frequency of pregnancy check irregularities as much as $54.5 \%$, the relationship between the level of education and the frequency of antenatal care was chi-square 0,143>0,05. Result in this study there was a relationship between the level education of pregnant women with the frequency of antenatal care
\end{abstract}

Keywords: Education, Frequency, Pregnancy. 


\section{PENDAHULUAN}

AKI kembali menunjukkan penurunan menjadi 305 kematian ibu per 100.000 kelahiran hidup berdasarkan hasil Survei Penduduk Antar Sensus (SUPAS) 2015 (Kemenkes Republik Indonesia, 2016). Secara nasional, cakupan pelayanan kesehatan ibu hamil K4 pada tahun 2016 telah memenuhi target rencana strategis (Renstra) kementerian kesehatan sebesar $74 \%$. Namun demikian, terdapat sembilan provinsi yang belum mencapai target tersebut yaitu Maluku Utara, Papua, Nusa Tenggara Timur, Papua Barat, Jambi, Maluku, Sulawesi Barat, Sulawesi Tenggara dan DI Yogyakarta (Kemenkes Republik Indonesia, 2016).

Menurut Sari dan Efendy (2017) banyak faktor yang mempengaruhi kunjungan antenatal care pada ibu hamil. Secara umum kunjungan kesehatan ibu hamil erat hubungannya dengan kemiskinan, pendidikan, faktor geografis dan pembangunan sosial. Ibu hamil dari keluarga miskin yang tidak memiliki latar belakang pendidikan yang memadai cenderung mengalami kesulitan dalam melakukan kunjungan ke fasilitas pelayanan kesehatan karena keterbatasan biaya dan ketidaktahuan. Peran bidan dalam kunjungan antenatal care sesuai dengan standar kompetensi kebidanan berdasarkan Kepmenkes

Nomor 369/MENKES/SK/III/2007 pada kompetensi ketiga yaitu bidan memberi asuhan antenatal bermutu tinggi untuk mengoptimalkan kesehatan selama kehamilan yang meliputi deteksi dini, pengobatan atau rujukan dari komplikasi tertentu (Departemen Kesehatan Republik Indonesia, 2008).

Pendidikan sangat berperan dalam tingkat kematian perinatal. Tingkat kematian perinatal tertinggi (66 kematian per 1.000 kehamilan) adalah pada wanita tidak berpendidikan. Angka kematian perinatal turun lebih dari separuh (28 kematian per 1.000 kehamilan) untuk wanita yang tidak tamat SD (SDKI, 2017).

Pendidikan merupakan metode yang diterapkan di lingungan masyarakat yang bertujuan untuk meningkatkan kemampuan berpikir yang dimiliki masyarakat. Semakin tinggi tingkat pendidikan yang dimiliki maka akan semakin baik pula cara berpikir yang dimiliki oleh seseorang. Hal ini dikarenakan selama proses pendidikan seseorang akan dipaksa untuk mengembangkan pola berpikir yang dimiliki untuk menangkap setiap materi yang disampaikan, menerima setiap ilmu yang diajarkan dan diajak untuk berpikir logis dalam menyelesaikan setiap soal yang diajukan. Dengan adanya metode seperti ini secara tidak langsung dalam diri seseorang akan terjadi proses untuk belajar. Ibu hamil yang memiliki latar belakang pendidikan dalam kategori cukup, dalam dirinya sudah memiliki dasar untuk bisa berpikir secara logis untuk menyikapi mengenai kunjungan antenatal care. Ibu akan mencoba untuk menimbang baik dan buruknya melakukan 
kunjungan antenatal care (Sari dan Efendy, 2017).

Bidan sebagai seorang tenaga kesehatan yang memiliki peranan penting dalam menurunkan angka kematian ibu dan bayi, perlu terus melakukan monitoring secara berelanjutan. Memberikan pendampingan dan informasi mengenai masalah yang berhubungan dengan kesehatan ibu dan anak terutama dimasamasa kehamilan.

Tujuan dari penelitian tentang hubungan tingkat pendidikan ibu hamil terhadap frekuensi pemeriksaan kehamilan meliputi tujuan umum: mengetahui hubungan tingkat pendidikan ibu hamil terhadap frekuensi pemeriksaan kehamilan di BPM G.N. Maya D. Tambak Sawah. Sedangkan tujuan khusus: mengidentifikasi tingkat pendidikan ibu hamil di BPM G. N. Maya D. Tambak Sawah, mengidentifikasi frekuensi pemeriksaan kehamilan di BPM G.N. Maya D. Tambak Sawah, dan mengetahui hubungan tingkat pendidikan ibu hamil terhadap frekuensi pemeriksaan kehamilan di BPM G.N. Maya D. Tambak Sawah.

\section{METODE}

Jenis penelitian yang digunakan adalah penelitian kuantitatif menggunakan pola latar deduktif-induktif. Dengan desain penelitian cross sectional. Penelitian ini dilakukan pada bulan Mei - Juli 2019 di BPM Maya Waru - Sidoarjo. Subyek penelitiannya adalah ibu hamil yang melakukan pemeriksaan BPM G.N. Maya D. Prosedur penelitian yaitu dengan melakukan pengambilan sampel sebanyak 33 responden dari jumlah populasi sebanyak 36 responden. Kemudian seluruh sampel yang diambil diberikan kuesioner yang berisi tentan pendidikan dan frekuensi pemeriksaan kehamilan. Setelah itu data dikumpulkan dan melakukan analisis data melalui SPSS 20. Dengan tingkat nilai kemaknaan $\alpha=0.05$. Bila uji Asymp.sig pada tabel chi square $>0,05$ maka $\mathrm{H} 1$ diterima dan terdapat hubungan.

\section{HASIL}

\section{a. Data Penelitian}

Tabel 1 Distribusi frekuensi tingkat pendidikan ibu hamil di BPM G.N. Maya D Tambak Sawah.

\begin{tabular}{lcc}
\hline $\begin{array}{c}\text { Pendidikan } \\
\text { Responden }\end{array}$ & $\begin{array}{c}\text { Jumlah } \\
\text { Responden }\end{array}$ & $\begin{array}{c}\text { Persentase } \\
(\%)\end{array}$ \\
\hline Dasar & 18 & 54,5 \\
Menengah & 12 & 36,4 \\
Tinggi & 3 & 9,1 \\
\hline Total & $\mathbf{3 3}$ & $\mathbf{1 0 0 , 0}$ \\
\hline
\end{tabular}

Sumber: hasil analisis data September 2019

Berdasarkan tabel 1 diatas menunjukkan bahwa tingkat pendidikan ibu hamil sebagian besar adalah pendidikan dasar yaitu 18 orang (54,5\%), dan sebagian kecil adalah pendidikan tinggi yaitu 3 orang $(9,1 \%)$.

\section{Tabel 2 Deskripsi frekuensi pemeriksaan di BPM G.N. Maya. D}

\begin{tabular}{lcc}
\hline Keteraturan & $\begin{array}{c}\text { Jumlah } \\
\text { Responden }\end{array}$ & $\begin{array}{c}\text { Persentase } \\
(\%)\end{array}$ \\
\hline Teratur & 15 & 45,5 \\
Tidak & 18 & 54,5 \\
Teratur & $\mathbf{3 3}$ & $\mathbf{1 0 0 , 0}$ \\
\hline Total & \\
\hline
\end{tabular}


Sumber: hasil analisis data September 2019

Berdasarkan tabel 2 diatas menunjukkan bahwa Menunjukkan bahwa sebagian besar ibu hamil tidak teratur periksa yaitu 18 orang $(54,5 \%)$ dan yang teratur periksa hamil adalah 15 orang $(45,5 \%)$.

\begin{tabular}{|c|c|c|c|c|c|c|}
\hline \multirow{3}{*}{$\begin{array}{c}\text { Tingkat } \\
\text { Pendidikan }\end{array}$} & \multicolumn{4}{|c|}{$\begin{array}{c}\text { Frekuensi } \\
\begin{array}{c}\text { Pemeriksaan Ibu } \\
\text { Hamil }\end{array}\end{array}$} & \multirow{2}{*}{\multicolumn{2}{|c|}{ Jumlah }} \\
\hline & \multicolumn{2}{|c|}{ Teratur } & \multicolumn{2}{|c|}{$\begin{array}{l}\text { Tidak } \\
\text { teratur }\end{array}$} & & \\
\hline & $\mathbf{n}$ & $\%$ & $\mathbf{n}$ & $\%$ & $\mathbf{n}$ & $\%$ \\
\hline Dasar & - & - & 18 & 54,5 & 18 & 54,5 \\
\hline Menengah & 12 & 36,4 & - & - & 12 & 36,4 \\
\hline Tinggi & 3 & 9,1 & - & - & 3 & 9,1 \\
\hline Jumlah & 15 & 45,5 & 18 & 54.5 & 33 & 100 \\
\hline
\end{tabular}

Berdasarkan tabel 3 tabulasi silang diatas menjelaskan lbu hamil dengan pendidikan rendah sebagian besar (18 orang/54,5\%) tidak teratur periksa kehamilannya. Sedangkan yang berpendidikan menengah (12 orang/ $34,4 \%$ ) dan berpendidikan tinggi (3 orang $/ 9,1 \%$ ) teratur.

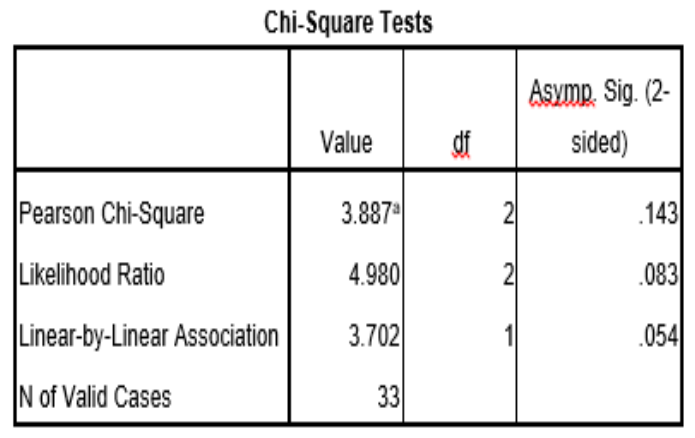

a. 2 cells $(33,3 \%)$ have expected count less than 5 . The minimum expected count is 5,27.

Dari tabel chi square dapat diketahui bahwa nilai Asymp.Sig adalah 0,143 lebih besar dari 0,05. Sehingga terdapat hubungan antara tingkat pendidikan dan frekuensi pemeriksaan.

\section{PEMBAHASAN}

\section{Tingkat Pendidikan Responden Di}

\section{BPM G.N. Maya. D}

Berdasarkan tabel 1, didapatkan bahwa $54,5 \%$ ibu hamil berpendidikan rendah. Dari hasil yang didapat bahwa dengan pendidikan yang rendah maka pengetahuan lbu hamil tentang pemeriksaan kehamilan juga rendah. Hal tersebut ternyata ada kesesuaian dengan teori yang ada yaitu semakin tinggi tingkat pendidikan seseorang maka semakin tinggi pula tingkat pengetahuan yang ia miliki dan semakin mudah memahami informasi yang disampaikan. Koentjoroningrat (2009) menyatakan bahwa orang yang berpendidikan rendah merasa tidak perlu untuk memeriksakan kehamilannya. 
2. Frekuensi Pemeriksaan Kehamilan Responden Di BPM G.N. Maya. D

Berdasarkan Tabel 4.2 didapatkan $45,5 \%$ ibu hamil tidak teratur periksa. Menurut peneliti hal ini dapat terjadi karena dipengaruhi oleh beberapa hal, diantaranya adalah pendidikan yang rendah. Pada proses pendidikan tersebut mengarahkan seseorang kearah perubahan dari tahu, menjadi memahami kemudian mengartikan apa yang dipahami setelah seseorang itu memahami kemudian dianalisa, dimana hasil analisa ini akan dihubungkan dan kemudian dievaluasi. Dari hal tersebut diatas maka seseorang dapat dikatakan belajar apabila di dalam proses belajar tersebut terjadi perubahan dari yang tidak tahu menjadi tahu dan dari yang tidak mengerjakan menjadi mengerjakan. (Notoatmodjo, 2010)

\section{Hubungan Tingkat Pendidikan} Terhadap Frekuensi Pemeriksaan Kehamilan di BPM G.N. Maya. D

Berdasarkan hasil penelitian diatas didapatkan hubungan antara tingkat pendidikan terhadap frekuensi pemeriksaan kehamilan dengan nilai chi-square adalah $0,143>0,05$. Hal ini dapat terjadi karena factor pendidikan seseorang merupakan pendorong terbentuknya perilaku sehat. Semakin tinggi tingkat pendidikan seseorang maka semakin tinggi kebutuhan akan pelayanan kesehatan seseorang. Juga ditunjang oleh semakin meluasnya wawasan keilmuan dan pengetahuan seseorang yang mana diperlukan adanya dukungan status ekonomi yang baik akan mendorong seseorang menyadari dan memahami adanya masalah kesehatan (Notoatmodjo, 2010). Menurut penelitian Ningsih (2017), semakin tinggi pendidikan seseorang akan mempengaruhi perilaku seseorang untuk melakukan kunjungan. Sebaliknya pendidikan yang kurang akan lebih sulit dalam mempersepsi dan menghambat perkembangan sikap ibu terhadap nilai-nilai yang baru diperkenalkan, seperti pentingnya kunjungan ANC pada saat hamil. Menurut penelitian Mukaromah dan Saenum (2014) pendidikan adalah salah satu cara ibu hamil menerima pengetahuan tentang antenatal care. Pendidikan yang tinggi dan pengetahuan yang baik akan membuat ibu hamil mudah menerima informasi dan melakukan kunjungan antenatal dengan teratur. Ibu hamil yang berpendidikan tinggi akan memeriksakan kehamilannya dengan sesuai demi menjaga keadaan kesehatan dirinya dan anak dalam kandungannya. Hal ini sesuai dengan penelitian Sari, Fitriana, \& Anggraini (2015) yang mengatakan bahwa semakin tinggi pendidikan ibu hamil maka akan lebih sering datang ke fasilitas kesehatan untuk memeriksakan kehamilannya. Pendidikan merupakan 
metode yang diterapkan di lingungan masyarakat yang bertujuan untuk meningkatkan kemampuan berpikir yang dimiliki masyarakat. Semakin tinggi tingkat pendidikan yang dimiliki maka akan semakin baik pula cara berpikir yang dimiliki oleh seseorang. Hal ini dikarenakan selama proses pendidikan seseorang akan dipaksa untuk mengembangkan pola berpikir yang dimiliki untuk menangkap setiap materi yang disampaikan, menerima setiap ilmu yang diajarkan dan diajak untuk berpikir logis dalam menyelesaikan setiap soal yang diajukan. Dengan adanya metode seperti ini secara tidak langsung dalam diri seseorang akan terjadi proses untuk menyikapi setiap permasalahan secara logis sesuai dengan kajian keilmuan. Ibu hamil yang memiliki latar belakang pendidikan dalam kategori cukup, dalam dirinya sudah memiliki dasar untuk bisa berpikir secara logis untuk menyikapi mengenai kunjungan antenatal care. Ibu akan mencoba untuk menimbang baik dan buruknya melakukan kunjungan antenatal care (Sari dan Efendy, 2017).

\section{SIMPULAN DAN SARAN}

\section{Simpulan}

Berdasarkan penelitian dan pembahasan melalui analisis antara varibel dependen dan independen maka dapat dirumuskan kesimpulan. Setengah dari responden yang memeriksakan kehamilanya di BPM G. N. Maya D sebagian besar 18 responden (54,5\%) mempunyai pendidikan dasar. Setengah dari responden yang memeriksakan kehamilanya di BPM G. N. Maya $D$ sebagian besar 18 responden $(54,5 \%)$ mempunyai pendidikan dasar. Ada hubungan antara tingkat pendidikan ibu hamil terhadap frekuensi pemeriksaan kehamilan. Karena nilai dari Asymp.Sig adalah 0,143 > dari 0,05 berarti $\mathrm{H}_{1}$ diterima dan artinya ada hubungan tingkat pendidikan ibu hamil terhadap frekuensi pemeriksaan kehamilan.

\section{Saran}

Bagi instansi diharapkan mengoptimalkan dalam pemantauan ibu hamil di sekitar wilayah untuk lebih sering memeriksakan kese-hatannya. Dalam peningkatan cakupan frekuensi pemeriksaan kehamilan secara rutin. Lebih meningkatkan mutu pelayanan khususnya di bidang kebidanan, terutama perawatan pada ibu dan anak khususnya pemeriksaan kehamilan, pentingnya melakukan konse-ling dalam pemeriksaan dang mengingatkan ibu untuk melakukan pemeriksaan secara rutin. Dan peneliti selanjutnya adanya penelitian lebih lanjut mengenai faktor - faktor lain yang mempengaruhi frekuensi pemeriksaan.

\section{DAFTAR PUSTAKA}

Departemen Kesehatan Republik Indonesia. 2008. Standar Profesi Bidan. Jakarta.

Kemenkes Republik Indonesia. 2016. Profil Kesehatan Indonesia Tahun 2016. Retrieved from http://www.depkes.go.id/ resources/download/pusdatin/profil- 
kesehatan-indonesia/Profil-

Kesehatan-Indonesia-2016.pdf.

Koentjaraningrat. 2009. Pengantar IImu

Antropologi. Jakarta: RinekaCipta

Mukaromah, H., \& Saenum. 2014. Analisis

Faktor Ibu Hamil Terhadap Kunjungan

Antenatal Care di Puskesmas

Siwalankerto Kecamatan Wonocolo

Kota Surabaya. Jurnal Promosi Dan

Pendidikan Kesehatan Indonesia,

2(1), 39-48.

Notoatmodjo S. 2010.llmu Perilaku

Kesehatan. Jakarta: Rineka Cipta.

Ningsih, E. S. 2017. Hubungan Tingkat Pendidikan Ibu Hamil Trimester III dengan Keteraturan Kunjungan ANC. Jurnal Midpro, 9(2).

Sari, G. N., Fitriana, S., Anggraini, D. H. 2015. Faktor Pendidikan, Pengetahuan, Paritas, Dukungan Keluarga dan Penghasilan Keluarga yang Berhubungan dengan Pemanfaatan Pelayanan Antenatal. Jurnal IImu Dan Teknologi Kesehatan, 2(2): 77-82.

Sari, K. I. P., Efendy, H. V. 2017. Analisis Faktor yang Berpengaruh terhadap Kunjungan Antenatal Care. Jurnal Keperawatan Dan Kebidanan, 9(1).

SDKI. 2017. Profil angka kematian.

http://sdki.bkkbn.go.id/?lang=id\&what $=$ book 